\title{
METHODOLOGY OF RESEARCH OF WORLD ECONOMY AS THREE-SECTOR SYSTEM OF ECONOMICS IN CONDITIONS OF FINANCIAL GLOBALIZATION
}

\author{
I.Sh. Khasanov \\ Institute of Management, Economics and Finance \\ Kazan Federal University \\ Kazan, Russia \\ e-mail: ilgizarkhasan@mail.ru
}

\begin{abstract}
In the world economy, exporting countries, which supply goods, importing countries that form demand for goods, interact, and third countries act as exporters and importers. Products and services that are traded on world markets are the goods of three sectors (groups of industries) of the national economy of any country. Therefore, the subject and the method of studying the global economy is a three-sector model of the world economic system.
\end{abstract}

Keywords - exporters, importers, three sectors, capital and consumer goods, financial services, three-sector model, world economic system.

\section{INTRODUCTION}

Under present conditions, it is quite obvious that both the crisis of fundamental economic science and the crisis of the practice of the global economy are marked. During the last century, the world capitalist system finally emerged and even its peculiarities appeared at the stage of globalization. This served as a basis for some scientists to begin to identify the patterns of development of global capitalism [1-18]. At present, the world economy is a single global economic system with complex connections between its elements, in which almost all countries, including the former socialist states, act. The global economic crisis of 2008-2009 was a graphic illustration of the close internal interconnection of all countries and all sectors of economies, as well as the high vulnerability of the modern global capitalist system.

The world economy, unlike the national economy of a particular country, has the following features. When the national economy of a particular country is studied, then an individual reproduction process is considered, i.e. production, distribution, exchange and consumption of gross output and domestic product of a particular country. As you know, the reproductive process of a particular country is carried out due to the fact that part of the gross output and national product is sold on the domestic market of the country, and the other part on the external world markets. Therefore, the subject of studying the national economy is mainly the mechanism of functioning of domestic markets and their impact on the reproduction process. When the world economy is studied, then the subject of research is the mechanism of functioning of world markets due to gross output and national product coming to the rest of the world from national economies, as well as their influence on the reproduction process of all countries. Thus, the world economy is, as a comparison, a certain reservoir in which "water resources" flow in the form of goods exported by some countries (products, services, works and other assets) and "water resources" flow out in the form of goods imported by other countries to maintain the national economy in an equilibrium state. Thanks to the world economy and its markets, there is a specific exchange of goods for income between its individual territories (regions), which can be individual countries or associations of countries. When studying the world economy, it is necessary to focus on international economic relations, world markets and their influence as an external factor on the national economies of individual countries.

\section{METHOD}

What does the national economy of each country connect with the world commodity markets or the world economy? Each country with its national economy as a subject of international economic relations is characterized, in our opinion, primarily by the fact that it can have three variants of behavior: act only as an exporter, or only as an importer of goods and, finally, as an exporter and importer at the same time. In the first case, a certain state implements on the world markets a proposal (as a seller) of goods and forms foreign exchange earnings, in the second case acts as a buyer and carries out demand in exchange for its foreign exchange earnings, and in the third case it is both a seller and a buyer of goods. Therefore, countries of the world can be classified into countries net exporters and net importers, i.e. having respectively excess of exports over imports or vice versa, as well as countries that have the equality of exports and imports of goods

An important criterion in the classification of countries is the qualitative characteristics of exported and imported goods. In our opinion, the most common grouping of goods at use value is the following classification: 
- goods of industrial purpose, according to K. Marx, the products of the branches of division I, and according to J.M. Keynes, capital goods [19];

- goods of consumer purpose, according to Karl Marx's views, the products of the branches of division II, and according to J. M. Keynes, consumer goods [20];

- financial, credit, foreign exchange and other similar values; securities of corporations, precious metals and stones, derivatives and other so-called instruments of monetary, credit and other financial markets;

- movable and immovable luxury in the form of land, castles, art valuables, antiques, jewelry, historical artifacts, expensive ships, aircraft, cars and other vehicles;

- objects of intellectual property: scientific discoveries and inventions, modern technologies and similar goods;

- products of the military-industrial complex, military services, equipment and technologies, movable and immovable property of military purpose;

- non-reproducible natural resources that are in real ownership [9].

The above-mentioned grouping can also be detailed by dividing into products-goods, services-goods and work-goods, as well as goods produced and consumed by organizations, in particular transnational corporations, and goods consumed by the broad strata of the population (wage labor) and the rich population (the owners of various assets). With the second half of the $\mathrm{XX}$, it becomes important to divide both the national economy and the world economy at least into the following sectors:

- sector of economy, which produces the various types of economic activities, such as goods-products, goods-works (construction, research, etc.) and goods-services of industrial purpose (capital goods) for organizations;

- sector of economy, which produces consumer products and services for individuals or consumer goods for the population;

- sector of economic activities that provide financial and credit services, carrying out transactions with real estate, luxury goods for organizations and individuals.

\section{RESULT}

Recognition of the division of the national economy into two sectors (according to Karl Marx - into two subdivisions, and according to J.M. Keynes - into two groups of industries), in our opinion, allowed many scientists in the 20th century to identify the following macroeconomic relationships between effective demand and supply; autonomous and stimulating investments; multiplier and accelerator; consumption and savings; marginal propensity to consume and investment; multiplier of investments and employment; investments and savings; wages and employment [21].

The study of the reproductive process of the national economy using a two-sector approach (division of the macroeconomics into groups of industries producing means of production and consumer goods) made it possible to determine the factors influencing the rate of its economic growth [22; 23]. The study of the world economic relations of the global economy from the point of view of its division into the above three sectors makes it possible to discover the modern laws of the reproduction process, to determine the factors of economic growth and the causes of the global crisis of the mega economy.

The most important methodological prerequisite for the reproductive process of the world economic system and its growth is the equality of aggregate demand and aggregate supply in world markets: consumer goods and services to the population; capital goods and services (means of production and production services to organizations); financial and credit services to organizations and individuals (in financial markets). The equilibrium condition of the world economic system can be observed only if proportional development of the above sectors of the world economy is observed. Under the proportional development of the three sectors of the world economy, we mean the equality of the aggregate of goods offered for sale in exchange for the effective demand of buyers of goods [24; 25]. The export of goods from national economies to world markets is a proposal, and the import of goods into national economies is a form of effective demand expression.

To consider the equilibrium state of the world economy, let us turn to the conditional scheme of extended public reproduction of the mega economy. Let us assume that in 2017, there are the following initial data on the state of global economic relations, exports of manufactured goods and, accordingly, imports of goods on world markets:

$$
\begin{aligned}
& \text { I. } 2500 \mathrm{c}_{1}+2000 \mathrm{v}_{1}+1500 \mathrm{~m}_{1}=6000 \mathrm{w}_{1} ; \\
& \text { II. } 2000 \mathrm{c}_{2}+1800 \mathrm{v}_{2}+2200 \mathrm{~m}_{2}=6000 \mathrm{w}_{2} ; \\
& \text { III. } 1000 \mathrm{c}_{3}+1800 \mathrm{v}_{3}+1200 \mathrm{~m}_{3}=4000 \mathrm{w}_{3} ; \\
& 5500 \mathrm{c}+5600 \mathrm{v}+4900 \mathrm{~m}=16000 \mathrm{w}
\end{aligned}
$$

where I, II, III - respectively, the first, second and third sectors of the world economy. The first sector is the production of capital goods, the second is production of consumer goods, including services, for the population, and the third is financial services for the population and organizations;

$-\mathrm{c}_{1}, \mathrm{c}_{2}, \mathrm{c}_{3}-$ material costs and depreciation in the gross output of exported goods, respectively, in the first, second and third sectors of the world economy;

$-\mathrm{v}_{1}, \mathrm{v}_{2}, \mathrm{v}_{3}-$ the costs of living labor (wages of employees) in the gross output of exported goods, respectively, in the first, second and third sectors of the world economy;

- $\mathrm{m}_{1}, \mathrm{~m}_{2}, \mathrm{~m}_{3}-$ surplus value (in monetary terms, gross profit) in the gross output of exported goods, respectively, in the first, second and third sectors of the world economy;

$-\mathrm{w}_{1}, \mathrm{w}_{2}, \mathrm{w}_{3}-$ gross output of goods, respectively, in the first, second and third sectors of the world economy. All the conventions adopted by us correspond to the available statistical data in the international system of national accounts. 
In the above system of equations, all the conditions of the extended reproduction process and the growth of the world economic system are observed. The first condition means the excess production of the means of production of the first sector of the world economy (which determines the corresponding value of supply in world markets, i.e. exports of goods from national economies) over the consumed means of production in the three sectors of the national economies of countries (which causes the corresponding demand or imports into national economies):

$2500 c_{1}+2000 v_{1}+1500 m_{1}>2500 c_{1}+2000 c_{2}++1000 c_{3}$ or $2000 \mathrm{v}_{1}+1500 \mathrm{~m}_{1}>>2000 \mathrm{c}_{2}+1000 \mathrm{c}_{3}$.

Consequently, this condition allows additional investments in real sectors of national economies or expanded reproduction of gross output and national product in the next period of time (for example, in 2018).

From the second condition it follows that the aggregate national income of the countries of the world, obtained through the export of goods to world markets, exceeds the consumer goods and financial services that they export for households (the population): $5600 v+4900 \mathrm{~m}>\left(2000 \mathrm{c}_{2}+\right.$ $\left.1800 \mathrm{v}_{2}+2200 \mathrm{~m}_{2}\right)+\left(1000 \mathrm{c}_{3}+1800 \mathrm{v}_{3}+1200 \mathrm{~m}_{3}\right)$.

This condition means that the national income can be used not only for the purpose of consumption, but also for real investments and investments in financial assets.

Based on the equilibrium condition of the world economic system, the distribution of the gross output of goods exported to world markets and goods imported from world markets, as well as of the gross national product, could be carried out in 2017 as follows. Conditions for the equality of the aggregate supply to world markets (exports of goods) and aggregate demand in world markets (imports of goods):

$$
\begin{aligned}
& \text { I. } 2500 \mathrm{c}_{1}+278 \Delta \mathrm{c}_{1}+2000 \mathrm{v}_{1}+224 \Delta \mathrm{v}_{1}+998 \mathrm{~m}_{1} / \mathrm{x}=6000 \mathrm{w}_{1} \text {; } \\
& \text { II. } 2000 \mathrm{c}_{2}+148 \Delta \mathrm{c}_{2}+1800 \mathrm{v}_{2}+134 \Delta \mathrm{v}_{2}+1918 \mathrm{~m}_{2} / \mathrm{x}=6000 \mathrm{w}_{2} \text {; }
\end{aligned}
$$
$4000 \mathrm{w}_{3}$.

$$
\text { III. } 1000 c_{3}+74 \Delta c_{3}+1800 v_{3}+42 \Delta v_{3}+1084 m_{3} / x=
$$

$$
5500 \mathrm{c}+500 \Delta \mathrm{c}+5600 \mathrm{v}+400 \Delta \mathrm{v}+4000 \mathrm{~m} / \mathrm{x}=16000 \mathrm{w},
$$

where $\Delta \mathrm{c}_{1,2,3}$ - increase in material costs including the cost of consumption of fixed capital (depreciation charges) due to imports of goods from world markets, respectively, in the first, second and third sectors;

$-\Delta \mathrm{v}_{1,2,3}-$ increase in wages of hired workers and increase in consumption of consumer goods and services by the population due to their own cash income, as well as cash and in-kind payments from state and non-profit organizations;

$-\mathrm{m}_{1,2,3} / \mathrm{x}\left(\mathrm{m}_{1,2,3}-\Delta \mathrm{c}_{1,2,3}-\Delta \mathrm{v}_{1,2,3}\right)$ - the remaining part of the surplus value (net profit) used for the acquisition of financial and credit assets and other speculative purposes;

- $\mathrm{W}_{1,2,3}$ - gross output of products and services at market prices.

The goods of the first sector are fully realized in the direction of expansion of production in 2018, i.e. solvent demand for capital goods and services (imports into national economies of countries) is equal to the commodity supply (export of capital goods from national economies to world markets): $2500 c_{1}+278 \Delta c_{1}+2000 c_{2}+148 \Delta c_{2}+1000 c_{3}+74 \Delta c_{3}=$ $=2500 \mathrm{c}_{1}+278 \Delta \mathrm{c}_{1}+2000 \mathrm{v}_{1}+224 \Delta \mathrm{v}_{1}+998 \mathrm{~m}_{1} / \mathrm{z}$.

The distribution of the gross output of the second sector goods (consumer goods and services for the population) with the equality of demand (import) and supply (export) could be in 2017 as follows:

$$
\begin{aligned}
& 2000 v_{1}+224 \Delta v_{1}+1800 v_{2}+134 \Delta v_{2}+1800 v_{3}+42 \Delta v_{3}= \\
& =2000 c_{2}+148 \Delta c_{2}+1800 v_{2}+134 \Delta v_{2}+1918 m_{2} / x \text { or } \\
& 2000 v_{1}+224 \Delta v_{1}+1800 v_{3}+42 \Delta v_{3} \\
& 2000 c_{2}+148 \Delta c_{2}+1918 m_{2} / z
\end{aligned}
$$

From the above conditional scheme of the sectors of the economy, it can be seen that the share of sector I accounts for $37.5 \%$ of the total gross output of goods $(16000 \mathrm{w}),\left(6000 \mathrm{w}_{1}\right.$ : $16000 \mathrm{w} \times 100 \%)$, sector II $-37,5 \%\left(6000 \mathrm{w}_{2}: 16000 \mathrm{w} \times\right.$ $100 \%)$, and sector III $-25,0 \%\left(4000 \mathrm{w}_{2}: 16000 \mathrm{w} \times 100 \%\right)$.

Now let us look at how the financial and credit services could be implemented in the third financial sector of the world economy: $998 \mathrm{~m}_{1} / \mathrm{x}+1918 \mathrm{~m}_{2} / \mathrm{x}+1084 \mathrm{~m}_{3} / \mathrm{x}=$

$$
\begin{aligned}
& =1000 \mathrm{c}_{3}+74 \Delta \mathrm{c}_{3}+1800 \mathrm{v}_{3}+42 \Delta \mathrm{v}_{3}+1084 \mathrm{~m}_{3} / \mathrm{x} \text { or } \\
& 998 \mathrm{~m}_{1} / \mathrm{x}+1918 \mathrm{~m}_{2} / \mathrm{x}==1000 \mathrm{c}_{3}+74 \Delta \mathrm{c}_{3}+1800 \mathrm{v}_{3}+42 \Delta \mathrm{v}_{3}
\end{aligned}
$$

Thus, an important condition for the equilibrium of the global economic system is the equality of purchasing power of currency (mostly due to convertible currency) demand (imports), on the one hand, and demand (exports) of financial and credit services to the third sector of the world economy, on the other hand:

$\mathrm{m}_{1} / \mathrm{x}+\mathrm{m}_{2} / \mathrm{x}+\mathrm{m}_{3} / \mathrm{x}=\mathrm{c}_{3}+\Delta \mathrm{c}_{3}+\mathrm{v}_{3}+\Delta \mathrm{v}_{3}+\mathrm{m}_{3} / \mathrm{x}$.

These transactions are reflected in the international system of national accounts as net lending (+) or as net borrowing (-) in global financial markets.

As a result of international export-import transactions, transactions on world markets, the factors of production (capital and labor) could be divided among the three sectors by the beginning of 2018 as follows:

$$
\begin{aligned}
& \text { I. } 2778 \mathrm{c}_{1}+2224 \mathrm{v}_{1} \text {; } \\
& \text { II. } 2148 \mathrm{c}_{2}+1934 \mathrm{v}_{2} \text {; } \\
& \text { III. } 1074 \mathrm{c}_{3}+1842 \mathrm{v}_{3} \text {. }
\end{aligned}
$$

Then, if the organic structure of capital is preserved, the rate of surplus-value $\left(\mathrm{m}_{1}: \mathrm{v}_{1}=0,75 ; \mathrm{m}_{2}: \mathrm{v}_{2}=1,22 ; \mathrm{m}_{3}: \mathrm{v}_{3}=\right.$ $0,67)$ in 2018 , the following amounts of gross are released:

$$
\begin{aligned}
\text { I. } 2778 c_{1}+2224 v_{1}+1668 m_{1} & =6670 w_{1} \\
\text { II. } 2148 c_{2}+1934 v_{2}+2364 m_{2} & =6446 w_{2} \\
\text { III. } 1074 c_{3}+1842 v_{3}+1228 m_{3} & =4144 w_{3} . \\
6000 c+6000 v+5260 m & =17260 w .
\end{aligned}
$$

Thus, the aggregate output of gross output for export in world markets in 2018 may amount to 17,260 monetary units, i.e. economic growth can be equal to: $17260: 16000=$ 
1,07875 or an equal increase of $7,875 \%$. However, this is an abstract conditional example. The equilibrium in the world economic system depends on many factors. For the equilibrium of the world economic system and the rates of economic growth in the context of globalization (equality of aggregate demand and supply of goods of three sectors), the proportion in which profit (surplus value) is divided into accumulated $(\Delta \mathrm{c})$, consumed $(\Delta \mathrm{v})$ and transaction $(\mathrm{m} / \mathrm{x})$ parts, i.e. the surplus value (profit) breaks up into the following directions of use:

$$
\begin{aligned}
& \mathrm{m}_{1}=\Delta \mathrm{c}_{1}+\Delta \mathrm{v}_{1}+\mathrm{m}_{1} / \mathrm{x} ; \\
& \mathrm{m}_{2}=\Delta \mathrm{c}_{2}+\Delta \mathrm{v}_{2}++\mathrm{m}_{2} / \mathrm{x} ; \\
& \mathrm{m}_{3}=\Delta \mathrm{c}_{3}+\Delta \mathrm{v}_{3}+\mathrm{m}_{3} / \mathrm{x}, \text { or from here: } \\
& \mathrm{m}_{1} / \mathrm{x}=\mathrm{m}_{1}-\Delta \mathrm{c}_{1}-\Delta \mathrm{v}_{1} ; \\
& \mathrm{m}_{2} / \mathrm{x}=\mathrm{m}_{2}-\Delta \mathrm{c}_{2}-\Delta \mathrm{v}_{2} ; \\
& \mathrm{m}_{3} / \mathrm{x}=\mathrm{m}_{3}-\Delta \mathrm{c}_{3}-\Delta \mathrm{v}_{3} .
\end{aligned}
$$

For the further growth of the world economic system in the next period of time, it is necessary that the above conditions for the equality of supply (export) and the demand (import) of goods on world markets be respected. In reality, the world economic system strives for an equilibrium state through permanent inequalities and economic crises, i.e. capital and consumer goods, as well, as financial services, are exported and imported in larger or smaller amounts than is necessary for normal accumulation and consumption, i.e. the world economy can have the following possible conditions or inequalities for its development:

$$
\begin{aligned}
& \mathrm{c}_{2}+\Delta \mathrm{c}_{2}+\mathrm{c}_{3}+\Delta \mathrm{c}_{3}>\text { or }\left\langle\mathrm{v}_{1}+\Delta \mathrm{v}_{1}+\mathrm{m}_{1} / \mathrm{x}\right. \\
& \mathrm{v}_{1}+\Delta \mathrm{v}_{1}+\mathrm{v}_{3}+\Delta \mathrm{v}_{3}>\text { or }<\mathrm{c}_{2}+\Delta \mathrm{c}_{2}+\mathrm{m}_{2} / \mathrm{x} \\
& \mathrm{m}_{1} / \mathrm{x}+\mathrm{m}_{2} / \mathrm{x}+\mathrm{m}_{3} / \mathrm{x}>\text { or }\left\langle\mathrm{c}_{3}+\Delta \mathrm{c}_{3}+\mathrm{v}_{3}+\Delta \mathrm{v}_{3}+\mathrm{m}_{3} / \mathrm{x}\right.
\end{aligned}
$$

\section{CONCLUSION}

The above inequalities between the three sectors of the world economy arise for the following reasons: the discrepancy between demand (imports) and supply (exports) of goods in world markets; the changing organic structure of capital (c: v); the rate of surplus value ( $\mathrm{m}: \mathrm{v})$; division of surplus value and profit $(\mathrm{m})$ into the accumulation fund and consumption fund $(\Delta \mathrm{c}: \Delta \mathrm{v})$; use of profit on the purchase of financial assets $(\mathrm{m} / \mathrm{x})$ and the operation of economic laws of capitalism. If in the past century, at the stage of statemonopoly capitalism, economic laws clearly manifested their effect in different forms within the national economies of highly developed industrial states, then at the stage of globalization, the boundaries and scale of the laws of capitalism (social division of labor, surplus value and average rate of profit, payment labor (wages), the organic structure of capital, the improvement of productive forces and human capital, labor productivity, the market competition; the concentration and centralization of production and capital, reduce production costs, the cost and pricing, supply and demand, interest and rent and other) have increased their effect on the global economy. The global economic crisis of 2008-2009 is a confirmation of the epochs of global capitalism. The crisis began in one of the branches and types of banking operations in the economy (housing construction and mortgage lending) of a separate country (USA), then it covered all of its financial sector, and then caused a crisis of real sectors of national economies of most countries in the world. The causes of global capitalism are the same as those of capitalism at the previous stages of its development. They are of essential or natural character; only the forms of manifestation change.

\section{References}

[1] John A. Allison, The Financial Crisis and the Free Market Cur (Why Pure capitalism Is the World Economy's Only Hope), 2013, New York. The McGraw-Hill Companies.

[2] Edward E. Baptist, And Hyman Louis. American Capitalism. Simon and Schuster Paperbacks, New York, 2014.

[3] Ben S. Bernanke, The Courage to Act. A Memoir of a Crisis and Its Aftermath. W. W. Norton and Company, New York, London, 2015.

[4] Tony Crescenzi, Beyond the Keynesian Endpoint: Crushed by Credit and Deceived by Debt - How to Revive the Global Economy. Publishing as FT Press, New Jersey, 2012.

[5] Jean-Philippe, Delson and Nicolas Lecaussin and Emmanuel Martin. Anti-Piketty Cato Institute. Washington, 2017.

[6] Robert J. Gordon, The rise and fall of American growth: the U.S. standard of living since the Civil War, Princeton University Press. Princeton and Oxford, 2016.

[7] Thom Hartmann. The Crash of 2016, The Plot to Destroy America - and What We Can Do to Stop It. Twelve. Hachette Book Group. New York, 2013.

[8] Mervyn King, The End of Alchemy Money, Banking, and the Future of the Global Economy. WW. Norton and Company, New York, London, 2016.

[9] Parag Khanna, Connectography: mapping the future of global civilization, Random House, New York, 2016.

[10] Paul Krugman. The Return of Depression on Economics and the Crisis of 2008. W. W. Norton and Company. New York, London. 2009. 207P.

[11] Thomas Piketty, Capital in the Twenty First Century. The Belknap Press of Harvard University Press. Cambridge, Massachusetts, London, 2014.

[12] James Rickards. The Death of Money. The Coming Collapse of the International Monetary System. Portfolio. Penguin Group. New York. 2014. - 414P

[13] Jeffrey D.Sachs, The Price of civilization. Reawakening American Virtue and Prosperity. Random House Trade Paperbacks, New York, 2012.

[14] Robert J. Shiller, Irrational Exuberance. Princeton Univercity Press. Princeton, Oxford, 2015.

[15] Joseph E. Stiglitz, The Great Divide. Unequal Societies and What We Do About Them. W. W. Norton and Company, New York, London, 2015.

[16] Joseph E. Stiglitz. The Price of Inequality. W. W. Norton and Company. New York, London. 2013. - 523P.

[17] Joseph E. Stiglitz, The EURO, How a common currency threatens the future of Europe. W.W.Norton and Company. New York. London, 2016.

[18] David A. Stockman, The Great Deformation. The Corruption of Capitalism in America. Public Affairs. New York, 2013.

[19] J.M. Keynes, The general theory of employment, interest and money, Moscow: Helios ARV, 2002.

[20] K.Marx, Capital. Criticism of political economy, Vol. 2, Book. 2, The process of circulation of capital, Moscow: Politizdat, 1978.

[21] I.Sh. Khasanov, Transactional model of the economic system (dialectics of national accounting), Kazan, Publisher: Kazan federal University, 2008 .

[22] I.Sh. Khasanov, Public reproduction and formation of the transactional sector of the national economy of Russia in modern conditions, Kazan, Publisher: Kazan federal University, 2007. 
[23] I.Sh.Khasanov, Transactional sector of the economic system: national accounting of public reproduction. The author's abstract of the thesis for a doctor's degree in economics, Chelyabinsk, Chelyabinsk State University, 2009.

[24] I.Sh.Khasanov, K.I. Ayer, The financial sector of Russia at the stage of interation into the world economy (issues of theory, methodology and practice of national accounting), Kazan, Publisher: Kazan national research technological university, 2012.

[25] I.S.Khasanov, Three-sector structure of the national economy of Russia Asian Soial Science, no. 10, N 20, 2014 